\title{
Current concepts of neuropsychiatric systemic lupus erythematosus (NP-SLE)
}

\author{
Ronald A. Asherson, Susan D. Denburg', Judah A. Denburg', Ramona M. \\ Carbotte $^{1}$ and Nancy Futrell ${ }^{2}$
}

The Lupus/Arthritis Research Unit, The Rayne Institute, St Thomas' Hospital, London, SE1, 'Departments of Psychiatry and Medicine, Faculty of Health Sciences, McMaster University, 1200 Main Street West, Hamilton, Ontario, Canada L8N $3 Z 5$ and $^{2}$ Neurology Department, Creighton University School of Medicine, 601 N-30th Street, Omaha, Nebraska 68131-2197, USA

\section{Introduction}

Nervous system involvement in systemic lupus erythematosus (SLE) may present with diverse neurological or psychiatric symptomatology and may involve both central and peripheral dysfunction. Presentations may include stroke syndrome, seizures, psychoses, dementia, organic brain syndromes, chorea, coma as well as transverse myelopathy, peripheral neuropathy, myositis and a variety of syndromes affecting the optic nerves. Estimations of the prevalence of neuropsychiatric (NP) SLE vary from $14 \%$ to $75 \%$ reflecting variable diagnostic methodologies and criteria. ${ }^{1-9}$

In addition to these major clinical syndromes, patients with SLE may often be subject to 'soft' neurological and/or psychiatric problems, for example, parasthaesias, migraine-type headaches, anxiety states, mood swings, and cognitive problems such as difficulty in concentration, memory and word finding.

A few of the above symptomatologies may antedate the appearance of definitive, diagnosable SLE by months, or even years. An example of this is epilepsy, an isolated phenomenon which has been noted in childhood or early teens, only to be followed many years later by SLE. ${ }^{10}$ Chorea is another example of such a manifestation. ${ }^{11}$ It has recently become clear that many of the focal manifestations of NP-SLE such as transient ischaemic attacks (TIAs) or strokes may occur on the basis of vascular occlusions associated with anti-phospholipid antibodies (aPL). ${ }^{12-15}$ Epilepsy itself, as the sole manifestation of such vascular occlusions has also been associated with aPL. ${ }^{16,17}$ However, organic brain syndromes ${ }^{18}$ and multiinfarct dementias ${ }^{19,20}$ are examples of diffuse, nonfocal conditions also associated with this group of

Correspondence: R.A. Asherson, M.D., F.A.C.P., F.C.P.(S.A.), F.A.C.R.

Accepted: 4 February 1993 antibodies, so an attempted distinction into focal $\stackrel{\infty}{\infty}$ and diffuse is not as clear as originally conceived $\vec{A}$ with regard to the clinical presentations associated 8 with the aPL coagulopathy.

Neurological (or psychiatric) problems in lupus patients and their therapy confront the neurologist and rheumatologist with major therapeutic dilemmas. Should the patient receive 'pulse' steroids or cytotoxics and should these be combined with $\stackrel{\rho}{?}$ anticoagulant therapy if the aPL are presenf? $\overrightarrow{0}$ Anticoagulation alone may be sufficient in patien presenting with clearly focal vascular evente: Should psychotropics be administered to lup patients with predominantly psychiatric presentations? It is in the latter group of patients, particularly those who are on high-dose steroid therapy $\frac{\circ}{\Phi}$ and who may present with a psychotic state, that most diagnostic and therapeutic dilemmas occur. $\overrightarrow{\bar{\sigma}}$ Does the patient suffer from a primary psychiatric disorder, for example, manic depressive psychosis $/ \vec{F}$ schizophrenia, or is the condition solely lupus induced, and to what extent are the steroids contributing to the psychotic state? Some of these difficulties and some current concepts relating to NP-SLE will be addressed in this review article.

\section{Pathology}

The first study of pathology in patients with lupus presenting with neurological symptoms and signs $N$ was that by Kaposi in $1872 .{ }^{20} \mathrm{He}$ reported on patients with headache, delirium and coma and ${ }_{N}$ noted a variety of abnormalities, including cerebral $\omega$ atrophy and thickened, inflamed meninges. Subsequently, however, neurological abnormalities were $\stackrel{\varrho}{\subset}$ most often attributed to cerebral vasculitis, partic- $\mathbb{\infty}$ ularly if patients demonstrated vasculitis of other? organs, for example, the skin. ${ }^{21}$ No neuro- $\frac{T}{0}$ pathological correlations, however, were obtained. The first series correlating neurological dysfunc- 
tion and neuropathological findings was published by Johnson and Richardson in $1968 .^{22}$ They reported that true vasculitis in the brains of lupus patients was in fact rare, but that perivascular inflammation was more common. They also noted the frequent occurrence of microinfarcts and microhaemorrhages but were impressed that some patients with clinical evidence of neurological dysfunction appeared to have normal brains on postmortem evaluations. This rarity of cerebral vasculitis was confirmed at autopsy by Devinski and Petito in $1988^{23}$ who noted cardiac sources of emboli in the majority of their patients studied with stroke. Others have also reported this association, particularly with anti-phospholipid antibodies and stroke in patients with SLE. ${ }^{24-26}$

There is clearly no single clinical picture of NP-SLE, ${ }^{27}$ nor is there a single pathological feature of brain involvement in patients with the disease.

\section{Pathogenesis}

\section{(a) Anti-brain antibodies}

The puzzle, then, as to the pathogenesis in NPSLE, is the existence of those patients with definite brain dysfunction, who appear to have normal brains by both gross and microscopic evaluation at autopsy. ${ }^{23,28}$ Since autoantibodies are not seen with standard stains, it seems possible that an antibodymediated process could produce dysfunction in the absence of a demonstration of pathology when standard autopsy tests are used. It has previously been noted that antibody deposition may be seen in the choroid plexus. ${ }^{29}$ Because of the suggestion that lymphocytes and brain might share antigens which may both serve as targets for an autoimmune response, many studies have focused on the identity of these 'shared' antigens. ${ }^{28-34}$ In spontaneous SLE syndromes in mice, there is a high prevalence of antibodies directed against basic brain extracts, homogenates or tissue and in some mice these antibodies may be associated with the presence of learning and cognitive defects. ${ }^{35-40}$ It is therefore possible, that some, though not all, features of NP-SLE in humans might be mediated by these brain-reactive autoantibodies. Some of the antigens evoked as being implicated in the pathogenesis of NP-SLE are listed in Table I.

Lymphocyte/brain antigens include those related to microbial antigens, ${ }^{41}$ thymic-brain antigens, ${ }^{42}$ and T-cell antigens such as CD4, a specific receptor for the human immunodeficiency virus (HIV), ${ }^{43,44}$ which may mediate both AIDS dementia and NP-SLE. ${ }^{45-47}$ Antibodies to the suppressor T-lymphocyte molecule CD8, which have been found on myelin-producing oligodendrocytes, ${ }^{48}$ may explain involvement of T-suppressor cells or lymphocytotoxic antibodies in multiple sclerosis as well as NP-SLE. ${ }^{30,31,49-51}$ It has therefore been hypothesized that some cases of NP-SLE might involve $\mathrm{T}$-cell brain cross-reactive autoimmune responses, resulting in neuronal or glial cell loss, demyelination and/or inflammation in the brain.

Other candidate antigens include myelin-associated glycoprotein, an asialo-GM1 glycoprotein present on natural killer cells, as well as in central myelin. ${ }^{41,52,53}$ Antibodies against asialo-GM1 have been related temporally to exacerbations of NPSLE. ${ }^{54}$ Similar antibodies against mycobacterial glycosphingolipids may be associated with NPSLE. ${ }^{53-55}$ A recent study ${ }^{56}$ demonstrated antibodies to Semliki Forest virus (SFV) and to galactocerebrosides (GALC) in SLE patients as well as in patients with the 'primary' anti-phospholipid syndrome; the authors hypothesized that the antibody reactivity to SFV, particularly in the SLE anticardiolipin-positive patients appeared to be more specific than the reaction of antibodies to native GALC, and might represent reactivity to an undetermined glycophospholipid present in the envelope of some viruses such as SFV. ${ }^{56}$

Recently, several potential lymphocyte/brain antigens have been studied by immunoprecipitation techniques. ${ }^{32,57-61}$ Many SLE patients have significant elevations of autoantibodies which bind to neuroblastoma cells, ${ }^{61,62}$ which are lymphocytotoxic in vitro. ${ }^{32,33,51,59}$ The nature of the surface antigens against which IgG class antibodies are directed in sera and in cerebrospinal fluid of SLE patients has also been explored. ${ }^{62,63}$ These include a $97 \mathrm{kD}$ protein uniquely present on the surface of neuroblastoma cell lines ${ }^{60,61}$ and several determinants on the surface of peripheral blood lymphocytes or on CD4-positive lymphocytic cell lines. $32,60,64$

The most recent autoantibody candidates invoked in the causation of NP-SLE are the antibodies directed to anti-ribosomal $\mathbf{P}$, mostly seen in association with psychosis and depression. ${ }^{65-67}$ One patient with recurrent psychotic episodes studied recently was, however, negative for these antibodies in a prospective study.$^{67}$ However, a second more recent case study tended to confirm the original observations. ${ }^{68}$

Table I Antibodies implicated in pathogenesis of CNS lupus
1. CD4, CD8
2. Glycosphingolipids (mycobacterial)
3. Neuroblastoma cells
4. Thymic - brain antigens
5. Ribosomes (anti-ribosomal-P)
6. Phospholipids
7. Neurones
8. Galactocerebrosides 


\section{(b) Cytokines}

Some of the systemic manifestations of SLE, including uremia or hypoxemia, could adversely affect brain function in patients with lupus. ${ }^{69}$ One of the important groups of circulating factors which could produce brain dysfunction with resultant normal brain pathology are the cytokines, which are produced both by infectious agents as well as during inflammatory processes. Excess concentrations of cytokines can damage the brain and produce neurovascular lesions similar to those described in lupus. Clinically, IL-2-mediated neurological toxicity has certainly resulted from cytokine administration in cancer trials. ${ }^{70}$ Increased levels of IL-6 have been found in the cerebrospinal fluid of patients of NP-SLE and cerebritis due to infection. ${ }^{71-74}$ The presence of cytokine-containing cell populations in the hypothalamus ${ }^{75}$ as well as involvement of neuropeptides in immune regulation and in the synthesis of neuroendocrine-active molecules by lymphoid cells has been documented. ${ }^{76}$

Since abnormalities of both cytokine and antibody production occur with lupus, future studies of the mechanisms of brain dysfunction should include both a study of cytokines as well as antibodies in the sera and cerebrospinal fluid of lupus patients.

\section{Cognitive impairment}

A number of factors have been postulated as being involved in the production of cognitive impairment in SLE. These include: (1) the use of corticosteroids; (2) the non-specific effects of disease activity; and (3) psychological distress. Some of these will be briefly reviewed.

\section{Steroids}

Since high doses of corticosteroids have been reported as being associated with psychosis ${ }^{77}$ it is certainly plausible that corticosteroid therapy could, to some extent, contribute to cognitive impairment found in SLE patients. However, most investigators have found no significant association between cognitive impairment and either steroid therapy at the time of test ${ }^{78-82}$ or steroid dosage.$^{78,83}$ In fact it seems possible that steroid therapy may actually improve memory or other cognitive functions in SLE. Each of ten patients participating in single patient $(N=1)$ corticosteroid trials showed better performances after the first three week exposure to drug than to placebo, ${ }^{84}$ and Ginsburg et al: ${ }^{81}$ reported an association between steroid use and improved performance on complex attention tasks in their older SLE patients. Taken together, these findings strongly suggest that the higher prevalence of cognitive impairment in lupus patients cannot be attributed to corticosteroid treatment. A similar conclusion has in fact been $\stackrel{\varrho}{c}$ reached with respect to the possible effect of $\Rightarrow$ corticosteroids on the memory impairment $\stackrel{\vec{\rho}}{\rightarrow}$ documented in patients with multiple sclerosis. ${ }^{85}$

\section{Chronic disease}

Similarly, the contribution of chronic disease and/ or constitutional symptoms to cognitive impair- $\rightarrow$ ment has been evaluated. There was no significant $\stackrel{\circ}{\circ}$ association between cognitive impairment and $\overrightarrow{\vec{\omega}}$ scores on either the LACC (Lupus Activity Criteria $\stackrel{\omega}{\sigma}$ Count) ${ }^{78,79}$ an index of lupus activity which tallies $\bar{B}$ the number of active organ systems, ${ }^{86}$ the 3 . SLEDAI $^{83}$ and SLAM $^{81}$ scales, or other newer 8 indices of disease activity. ${ }^{87}$ It is worthwhile noting that a lack of association between the degree of $\vec{A}$ physical disability and significant cognitive func- $\delta$ tion, particularly memory impairment, has also $\mathrm{N}$ been reported in studies on patients with multiple 을 sclerosis. ${ }^{88,89}$ There have also been very few significant associations found between individual $\gg$ organ system involvement in SLE and cognitive impairment; in particular, patients with renal $\stackrel{\infty}{\oplus}$ involvement, which may be associated with $\mathrm{CNS} \overrightarrow{0}$ complications, were not more likely to show significant cognitive impairment than those wi skin and joint involvement. ${ }^{90}$ It is thus unlikely thä the high prevalence of significant cognitive impairment in SLE patients is simply a reflection of systemic illness.

\section{Psychological distress}

Lastly, although SLE patients experience and report considerable psychological distress, irres-? pective of whether their NP symptoms are active or $\bar{D}$ inactive, ${ }^{91,92}$ there is no significant association between the presence of emotional distress and $\frac{5}{3}$ cognitive impairment. ${ }^{78}$ This is consistent with a recent report of symptoms of anxiety and depres- $\frac{0}{3}$ sion in ambulatory SLE patients independent of

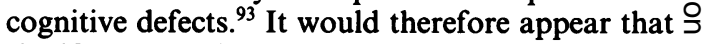
significant emotional distress is unlikely by itself to $\frac{D}{2}$ result in significant cognitive impairment in SLE, and, conversely, that emotional distress is not a necessary response to cognitive dysfunction. The two, however, may certainly co-occur. ${ }^{78}$

There is considerable diversity in the kinds of $\tilde{\omega}$ cognitive impairment shown by SLE patients, although memory problems are very common. ${ }^{94} \mathrm{C}$ Cognitive impairment has been found in up to one-half of SLE patients using quantitative criteria $\stackrel{?}{?}$ alone, reaching two-thirds if qualitative criteria ${ }_{0}$ (that is, test taking behaviours) are also con- $\frac{\mathrm{O}}{\mathrm{D}}$

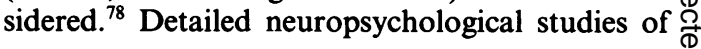


SLE patients have the potential to both contribute substantially to evaluation of the more subtle signs and symptoms of this form of impairment and possibly to redefine the criteria for diagnosing CNS involvement. They also provide invaluable information to the clinician to aid in patient counselling and management.

\section{Diagnosis}

A significant difficulty in establishing diagnostic criteria for NP-SLE is the absence of an acceptable gold standard. Electrophysiological, radiological and CSF analyses have been used with limited success. ${ }^{95}$ Magnetic resonance imaging (MRI) has been able to identify focal lesions undetected by CT scanning in patients with recent strokes or seizures. ${ }^{96,97}$ Patterns of MRI abnormalities have been found in association with the presence of anti-cardiolipin or anti-neurofilament antibodies. ${ }^{98}$ However, the value of MRI in documenting structural abnormalities related to minor CNS symptomatology or objectively documented cognitive dysfunction in SLE is unknown. Brain imaging based on metabolic function may prove to be even more sensitive than MRI in documenting central nervous involvement in SLE, for example, positron emission tomography (PET) is an even more sensitive method than MRI testing. Using this new methodology, abnormalities have been identified even when no structural lesions are evident on MRI. ${ }^{99-101}$ Studies of cerebral oxygen $\left(\mathrm{O}^{15}\right)$ consumption or regional blood flow $\left(\mathrm{Xe}^{133}\right)$ have revealed abnormalities which are suggestive of sub-clinical CNS involvement and changes have been seen with relapse and remission of CNS symptomatology. ${ }^{102-104}$ However, there have been no systematic, long-term studies of the functional (behavioural) correlates of changes in cerebral metabolism. Recently, a concordance between PET abnormalities and cognitive function has been reported in selected SLE patients. ${ }^{105}$ The potential utility of neuropsychological studies for delineating behavioural problems associated with CNS dysfunction as indicated by PET or other forms of brain imaging/scanning is therefore great.

A recent prospective study of the neuropsychiatric manifestations of SLE attempted to differentiate between primary involvement by the lupus process and secondary causes. ${ }^{106}$ Included in the primary group were psychoses, seizures, multiple cerebral infarction, papillitis, neuropathy and myelopathy. The commonest causes in the secondary group were infections, the administration of steroids, or encephalopathy associated with hypertension. These secondary patients manifested confusional states, seizures, headaches as well as psychosis (steroids). Infections included chronic bacterial (tuberculosis), fungal (aspergillus, cryptococcus, micormycosis, nocardia, or candida), acute bacterial (staphylococcus), klebsiella or viral (hepatitis, cytomegalovirus). These are most likely to result in major behavioural changes (suicide attempts, disorientation, major depression, confusion, hallucinations, states of altered alertness). These same manifestations were also noted in the series recently documented by Futrell et al.$^{27}$ who noted that these manifestations were often accompanied by contributing factors such as infections and/or azotaemia. The presence of systemic infection seem to occur most frequently in patients with decreased states of alertness. Steroids were only really implicated as a factor and were considered as a cause of psychosis in two patients in the previous study. ${ }^{106}$ Psychosis developed within 7 days after the commencement of prednisone $(60 \mathrm{mg}$ and $30 \mathrm{mg}$, respectively) in both patients. Both had active disease during the episodes of psychotic behaviour. The prednisone was reduced to $5 \mathrm{mg}$ daily and oral azathioprine and cyclophosphamide were given as steroid-sparing agents. The patients recovered without any neurological deficits.

There may on occasion be difficulties resulting from the differentiation of a primary lupus psychosis from steroid-induced states. Steroid psychosis in SLE patients is rare and appears in less than $5 \%$ of SLE patients. ${ }^{107}$ Several studies of steroid-induced psychiatric syndromes have shown that the predominant psychiatric manifestations appear to be changes in mood or affect (depression or mania), while frank psychosis is rare $(13 \%$ of cases only). ${ }^{108,109}$ The majority of patients, as in the two cases quoted above, developed their symptoms within 2 weeks of the commencement of steroid treatment and in most $(\mathbf{7 7 \%})$ the changes developed on doses greater than $40 \mathrm{mg}$. The mental changes resolved after between 2 and 60 days (with a mean of 24 days) following tapering of steroid dosage. In contrast to steroid-induced psychiatric syndromes, SLE patients have a high incidence of psychosis $(24 \%)$, the majority $(61 \%)$ of neuropsychiatric manifestations occur within the first year after the initial diagnosis of SLE and their frequency tends to decrease with time, but usually lasts longer than the steroid-induced psychotic conditions. ${ }^{110}$

In summary therefore, NP-SLE still remains a complex clinical situation with no single pathogenetic cause. The estimation of autoantibodies particularly those directed against cardiolipin, ribosomal-P and certain shared lymphocyte/brain antigens might assist in defining 'subsets'. Therapy still is individually 'tailored', although guiding principles enumerated in this article may certainly be of assistance in a particular case. 
1. Adelman, D.C., Saltiel, E. \& Klinenberg, J.R. The neuropsychiatric manifestations of systemic lupus erythematosus: an overview. Semin Arthritis Rheum 1986, 15: 185-199.

2. Bluestein, H.G. Nervous system disease in systemic lupus erythematosus. Immunol Allergy Clin North Am 1988, 8: 315-329.

3. Burnstein, S.L., Janoff, L. \& McCormick, K. Neuropsychiatric involvement in systemic lupus erythematosus: case report and review of the literature. J Am Osteopath Assoc 1987, 87: 626-631.

4. McCune, W.J. \& Golbus, J. Neuropsychiatric lupus. Rheum Dis Clin North Am 1988, 14: 149-167.

5. Bennahum, D.A. \& Mezner, R.P. Recent observations in central nervous system lupus erythematosus. Semin Arthritis Rheum 1975, 4: 253-266.

6. O'Connor, J.P. Diagnosis of central nervous system lupus. Can J Neurol Sci 1988, 15: 257-260.

7. O’Connor, J.P. \& Musher, D.M. Central nervous system involvement in systemic lupus erythematosus. Arch Neurol 1966, 14: 157-164.

8. Omdal, R., Mellgran, S.I. \& Husby, G. Clinical neuropsychiatric and neuromuscular manifestations in systemic lupus erythematosus. Scand J Rheumatol 1988, 17: 113-117.

9. Feinglass, E.J., Arnett, F.C., Dorsch, C.A. et al. Neuropsychiatric manifestations of systemic lupus erythematosus: diagnosis, clinical spectrum and relationship to other features of the disease. Medicine (Baltimore) 1976, 55: $323-329$.

10. Mackworth-Young, C.G. \& Hughes, G.R.V. Epilepsy: an early symptom of systemic lupus erythematosus. J Neurol Neurosurg Psychiat 1985, 48: 185-192.

11. Asherson, R.A., Derksen, R.H.W.M., Harris, E.N. et al. Chorea in systemic lupus erythematosus and lupus-like disease: association with antiphospholipid antibodies. Semin Arthritis Rheum 1987, 16: 253-259.

12. Asherson, R.A., Khamashta, M.A., Gil, A. et al. Cerebrovascular disease and antiphospholipid antibodies in systemic lupus erythematosus, lupus-like disease and the primary antiphospholipid syndrome. Am J Med 1989, 86: $391-399$.

13. Levine, S.R., Degan, M.J., Futrell, N. \& Welch, K.M.A. Cerebrovascular and neurologic disease associated with antiphospholipid antibodies: 48 cases. Neurology 1990, 40: 1181-1189.

14. Kushner, M.J. \& Simonian, N. Lupus anticoagulants, anticardiolipin antibodies and cerebral ischaemia. Stroke 1989, 20: 225-229.

15. Briley, D.P., Coull, B.M. \& Goodnight, S.H., Jr. Neurological disease associated with antiphospholipid antibodies. Ann Neurol 1989, 25: 221-227.

16. Herranz, M.T., Rivier, G., Khamashta, M. \& Hughes, G.R.V. Epilepsy associated with antiphospholipid antibodies in systemic lupus erythematosus. Proceedings of the 5th International Symposium on Antiphospholipid Antibodies, San Antonio, Texas, 1992, p. 38 (abstract).

17. Fields, R.A., Sibbitt, W.L., Toubbeh, H. \& Bankhurst, A.D. Neuropsychiatric lupus erythematosus, cerebral infarctions and anticardiolipin antibodies. Ann Rheum Dis 1990, 49: 114-117.

18. Asherson, R.A., Mercy, D., Phillips, G. et al. Recurrent stroke and multiinfarct dementia in systemic lupus erythematosus: association with antiphospholipid antibodies. Ann Rheum Dis 1987, 46: 605-611.

19. Coull, B.M., Bourdette, E.N., Goodnight, S.H., Jr. et al. Multiple cerebral infarctions and dementia associated with anticardiolipin antibodies. Stroke 1987, 18: 1107-1112.

20. Kaposi, M.K. Neue Beitrage zur Kenntniss des lupus erythematosus. Arch Derm Syph 1872, 360: 78.

21. Dubois, E.L. \& Tufanelli, D.L. Clinical manifestations of systemic lupus erythematosus: computer analysis of 520 cases. JAMA 1964, 190: 104-111.
22. Johnson, R.T. \& Richardson, E.P. The neurologica manifestations of systemic lupus erythematosus: a clinical $\$$ pathological study of 24 cases and review of the literature Medicine (Baltimore) 1968, 47: 337-369.

23. Devinsky, O., Pettito, C.K. \& Alonso, D.R. Clinical an $\overrightarrow{\text { 秀 }}$ neuropathological findings in systemic lupus erythematosus:. the role of vasculitis, heart emboli and thrombotic throme bocytopenic purpura. Ann Neurol 1988, 23: 380-384.

24. Asherson, R.A. \& Lubbe, W.F. Cerebral and valve lesions in SLE: association with antiphospholipid antibodie (editorial). J Rheumatol 1988, 15: 539-543.

25. Anderson, D., Bell, D., Large, R. \& Grant, E. Recurren岛 cerebral ischaemia and mitral valve vegetation in a patient. with antiphospholipid antibodies. $J$ Rheumatol 1987, 14 839-841.

26. D'Alton, J.G., Preston, D.N., Bormanis, J. et al. Multiplê transient ischaemic attacks, lupus anticoagulant and vere rucous endocarditis. Stroke 1985, 16: 512-514.

27. Futrell, N., Schultz, L.R. \& Millikan, C. Central nervous system disease in patients with systemic lupus erythe matosus. Neurology 1992, 42: 1649-1657.

28. Denburg, J.A., Carbotte, R.M. \& Denburg, S.D. Neuronabo antibodies and cognitive function in systemic lupus erythe $\vec{A}$ matosus. Neurology 1987, 37: 464-467.

29. Denburg, J.A. \& Temesvari, P. The pathogenesis of neuro psychiatric lupus. Can Med Assoc J 1983, 128: 257-260.

30. Bresnihan, B., Grigor, R.R. \& Hughes, G.R.V. Lymphocytotoxic antibodies in systemic lupus erythematosus:their clinical significance. J Clin Pathol 1979, 13: 112-11D

31. Bluestein, H.G. Autoantibodies to lymphocyte membrang antigens: pathogenetic implications. Clin Rheum Dis 1978, $\frac{50}{\omega}$ 643-659.

32. Long, A.A., Denburg, S.D., Carbotte, R.M., Singal, D.P Denburg, J.A. Serum lymphocytotoxic antibodies 世ndo neurocognitive function in systemic lupus erythematosus. Ann Rheum Dis 1990, 49: 249-253.

33. Temesvari, P., Denburg, J., Denburg, S., Carbotte, Benson, W. \& Singal, D. Serum lymphocytotoxic antibodies in neuropsychiatric lupus: a serial study. Clin Immunळ Immunopathol 1983, 28: 243-251.

34. Denburg, S.D., Carbotte, R.M., Long, A.A. \& Denburg J.A. Neuropsychological correlates of serum lympho cytotoxic antibodies in systemic lupus erythematosus. Brai Behav Immun 1988, 2: 222-234.

35. Forster, M.J., Retz, K.C. \& Lal, H. Learning and memory deficits associated with autoimmunity: significance in aging and Alzheimer's disease. Drug Dev Res 1988, 15: 253-273.

36. Hoffman, S.A., Narendran, A., Shucard, D.W. \& Harbeck R.J. Autoantibodies, immune complexes, and behaviouraP. disorders: neuropsychiatric involvement in systemic lupus erythematosus. Drug Dev Res 1988, 15: 237-251.

37. Fillit, H., Foley, P., Bradford, H.F. et al. Autoimmunity tó cholinergic-specific antigens of the brain in senile dementio of the Alzheimer's type. Drug Dev Res 1988, 15: 143-151

38. McRae-Degueurce, A., Haglid, K., Rosengren, L. et aP Antibodies recognizing cholinergic neurons and thyroglobulins are found in the cerebrospinal fluid of a subgrout of patients with Alzheimer's disease. Drug Dev Res 1988, 15 . 153-163.

39. Schwegler, H., Lipp, H.P. \& Crusio, W.E. NZB mouse? hippocampal mossy fiber patterns and behavioural profiles of young and older animals. Drug Dev Res 1988, 15U 297-305.

40. Sakic, B., Szechtman, H., Keffer, M., Talangbayan, HO Stead, R. \& Denburg, J.A. A behavioural profile of auteo immune lupus-prone MRL mice. Brain Behav Immun 1992 6: $265-285$.

41. Singh, V.K. \& Fudenberg, H.H. Can blood immunocytes be used to study neuropsychiatric disorders? J Clin Psychia? 1986, 47: 592-595. 
42. Reif, A.E. \& Allen, J.M.B. The AKR thymic antigen and its distribution in leukemias and nervous tissues. J Exp Med 1964, 120: 413-433.

43. Dalgleish, A., Beverley, P., Clapham, P., Crawford, D., Greaves, M. \& Weiss, R. The CD4 (T4) antigen is an essential component of the receptor for the AIDS retrovirus. Nature 1984, 312: 763-773.

44. Price, R.W. \& Brew, B. Infection of the central nervous system by human immunodeficiency virus: role of the immune system in pathogenesis. Ann NY Acad Sci 1988, 540: $162-175$.

45. Ziegler, J.L. \& Stites, D.P. Hypothesis: AIDS is an autoimmune disease directed at the immune system and triggered by a lymphotropic retrovirus. Clin Immunol Immunopathol 1986, 41: 305-313.

46. Kopelman, R.G. \& Zolla-Pozner, S. Association of human immunodeficiency virus infection and autoimmune phenomena. Am J Med 1988, 84: 82-88.

47. Query, C.C. \& Keene, J.D. A human autoimmune protein associated with UI RNA contains a region of homology that is cross-reactive with retroviral $\mathrm{p}^{30 \mathrm{gag}}$ antigen. Cell 1987, 51: 211-220.

48. Abramsky, O., Lisak, R.P., Silberberg, D.H. \& Pleasure, D.E. Antibodies to oligodendroglia in patients with multiple sclerosis. N Engl J Med 1977, 297: 1207-1211.

49. Steinberg, A.D. \& Klinman, D.M. Pathogenesis of systemic lupus erythematosus. Rheum Dis Clin North Am 1988, 14: 25-41.

50. Waksmann, B.H. Autoimmunity in demyelinating diseases. Ann NY Acad Sci 1988, 540: 13-24.

51. Winfield, J.B. Anti-lymphocyte antibodies in systemic lupus erythematosus. Clin Rheum Dis 1985, 11: 523-549.

52. McGarry, R.C., Helfand, S.L., Quarles, R.H. \& Roder, J.C. Recognition of myelin-associated glycoprotein by the monoclonal antibody, HNK-1. Nature 1983, 306: 376-378.

53. Endo, T., Scott, D.D., Stewart, S.S., Kundu, S.K. \& Marcus, D.M. Antibodies to glycosphingolipids in patients with multiple sclerosis and SLE. J Immunol 1984, 132: 1793-1797.

54. Hirano, T., Hashimoto, H., Shiokawa, Y. et al. Antiglycolipid autoantibody detected in the sera from systemic lupus erythematosus patients. J Clin Invest 1980, 66: 1437-1440.

55. Teplizki, H., Buskila, D., Argov, S. et al. Low serum antimycobacterial glycolipid antibody titers in the sera of patients with systemic lupus erythematosus associated with central nervous system involvement. J Rheumatol 1987, 14: 507-511.

56. Amor, S., Asherson, R.A., Webb, H.E. et al. Antibodies to Semliki Forest Virus (SFV) and galactocerebrosides (GACO) in SLE and primary antiphospholipid syndrome patients. Arthritis Rheuma 1992, 35: S.362 (abstract).

57. Minota, S. \& Winfield, J.B. Identification of three major target molecules of IgM antilymphocyte autoantibodies in systemic lupus erythematosus. J Immunol 1987, 139: 3644-3651.

58. Minota, S. \& Winfield, J.B. IgG anti-lymphocyte antibodies in systemic lupus erythematosus react with surface molecules shared by peripheral $\mathrm{T}$ cells and a primitive $\mathrm{T}$ cell line. J Immunol 1987, 138: 1750-1756.

59. Minota, S. \& Winfield, J.B. Nature of IgG anti-lymphocyte autoantibody-reactive molecules shed from activated T cells in systemic lupus erythematosus. Rheumatol Int 1988, 8: $165-170$.

60. Denburg, J.A. Clinical and subclinical involvement of the central nervous system in systemic lupus erythematosus. In: Waksman, B.H. (ed.) Immunologic Mechanisms in Neurologic and Psychiatric Disease. Raven Press, New York, 1990, pp. 171-178.

61. Hanly, J.G., Rajaraman, S., Behmann, S. \& Denburg, J.A. A novel neuronal antigen identified by sera from patients with systemic lupus erythematosus. Arthritis Rheum 1988, 31: $1492-1499$.
62. How, A., Dent, P.B., Liao, S.-K. \& Denburg, J.A. Antineuronal antibodies in neuropsychiatric systemic lupus erythematosus. Arthritis Rheum 1985, 28: 789-795.

63. Kelly, M.C. \& Denburg, J.A. Cerebrospinal fluid immunoglobulins and neuronal antibodies in neuropsychiatric systemic lupus erythematosus and related conditions. $J$ Rheumatol 1987, 14: 740-744.

64. Denburg, J.A., Behmann, S.A., Long, A.A., Carbotte, R.M. \& Denburg, S.D. Clinical associations of lymphocyte/ neuronal autoantibodies in SLE (abstract). Arthritis Rheum 1990, 33: S124.

65. Bonfa, E., Golombek, S.J., Kaufman, L.D. et al. Association between lupus psychosis and anti-ribosomal-P protein antibodies. $N$ Engl J Med 1987, 317: 265-271.

66. Schneebaum, A.B., Singleton, J.D., West, S.G. et al. Association of psychiatric manifestations with antibodies to ribosomal-P proteins in systemic lupus erythematosus. $\mathrm{Am} \mathrm{J}$ Med 1991, 90: 54-62.

67. Derksen, R.H.W.N., VanDan, A.P., Meyling, F.H.J.G. et al. A prospective study on anti-ribosomal p proteins in two cases of familial lupus and recurrent psychosis. Ann Rheum Dis 1990, 49: 779-782.

68. Kohen, N., Asherson, R.A., Gharavai, A. \& Lahita, R.G. Lupus psychosis: differentiation from steroid-induced state - value of anti-ribosomal P estimations. A case report. Clin Exp Rheumatol 1993 (in press).

69. Tarter, R.E., Van Thiel, D.H. \& Edwards, K.L. Medical Neuropsychology: The Impact of Disease on Behaviour. Plenum Press, New York, 1988.

70. Denicoff, K.D., Rubinow, D.R., Papa, M.Z. et al. The neuropsychiatric effect of treatment with interleukin-2 and lymphokine-activated killer cells. Ann Intern Med 1987, 107: 293-300.

71. Frei, K., Leist, T.P., Meager, A. et al. Production of B cell stimulatory factor-2 and interferon gamma in the central nervous system during viral meningitis and encephalitis: evaluation in a murine model infection and in patients. $J$ Exp Med 1988, 168: 449-453.

72. Houssiau, F.A., Bukasa, K., Sindic, C.J.M., Van Damme, J. \& Van Snick, J. Elevated levels of the $26 \mathrm{~K}$ human hybridoma growth factor (interleukin 6) in cerebrospinal fluid of patients with acute infection of the central nervous system. Clin Exp Immunol 1988, 71: 320-323.

73. Hirohata, S. \& Miyamoto, T. Elevated levels of interleukin6 in cerebrospinal fluid from patients with systemic lupus erythematosus and central nervous system involvement. Arthritis Rheum 1990, 33: 644-649.

74. Waage, A., Brandtzaeg, P., Halstensen, A., Kierulf, P. \& Espevik, T. The complex pattern of cytokines in serum from patients with meningococcal septic shock: association between interleukin 6 , interleukin 1 , and fatal outcome. $J$ Exp Med 1989, 169: 333-338.

75. Ricciardi-Castagloni, P., Pirami, L., Righi, M. et al. Cellular sources and effects of tumor necrosis factor-alpha on pituitary cells and in the central nervous system. Ann NY Acad Sci 1990, 594: 156-168.

76. O'Dorisio, M.S. \& Panerai, A. (eds). Neuropeptides and immunopeptides: messengers in a neuroimmune axis. Ann NY Acad Sci 1990, 594: 1-503.

77. Ling, M.H.M., Perry, P.H. \& Tsuang, M.T. Psychiatric side effects of corticosteroid therapy. Arch Gen Psychiatr 1981, 38: $471-477$.

78. Carbotte, R.M., Denburg, S.D. \& Denburg, J.A. Prevalence of cognitive impairment in systemic lupus erythematosus. $J$ Nerv Ment Dis 1986, 174: 357-364.

79. Hay, E.M., Black, D., Huddy, A. et al. Psychiatric disorder and cognitive impairment in systemic lupus erythematosus. Arthritis Rheum 1992, 35: 411-416.

80. Papero, P.H., Bluestein, H.G., White, P. \& Lipnick, R.N. Neuropsychologic deficits and antineuronal antibodies in pediatric systemic lupus erythematosus. Clin Exp Rheum 1990, 8: 417-424. 
81. Ginsburg, K.S., Wright, E.A., Larson, M.G. et al. A controlled study of the prevalence of cognitive dysfunction in randomly selected patients with systemic lupus erythematosus. Arthritis Rheum 1992, 35: 776-782.

82. Sonies, B.C., Klippel, J.H., Gerber, R.B. \& Gerber, L.H. Cognitive performance in systemic lupus erythematosus (abstract). Arthritis Rheum 1982, 25: 580.

83. Hanly, J., Fisk, J., Sherwood, G., Jones, E., Jones, J.V. \& Eastwood, B. Cognitive impairment in patients with systemic lupus erythematosus. $J$ Rheumatol 1992, 19: 562-567.

84. Denburg, S.D., Carbotte, R.M., Guyatt, G.H. \& Denburg, J.A. The effects of corticosteroids on neuropsychological functioning: results of single patient $(\mathrm{N}$ of 1$)$ trials $(\mathrm{Ab}$ stract). J Clin Exp Neuropsychol 1989, 11: 65.

85. Grafman, J., Rao, S.M. \& Litvan, I. Cognitive dysfunction in multiple sclerosis: disorders of memory. In: Rao, S.M (ed) Neurobehavioural Aspects of Multiple Sclerosis. Oxford University Press, New York, 1990, pp .102-117.

86. Urowitz, M.B., Gladman, D.D., Tozman, E.C.S. \& Goldsmith, C.H. The lupus activity criteria count (LACC). $J$ Rheumatol 1984, 11: 783-787.

87. Liang, M.H., Socher, S.A., Larson, M.G. \& Schur, P.H. Reliability and validity of six systems for the clinical assessment of disease activity in systemic lupus erythematosus. Arthritis Rheum 1989, 32: 1107-1118.

88. Rao, S.M., Leo, G.J. \& St Aubon-Faubert, P. On the nature of memory disturbance in multiple sclerosis. J Clin Exp Neuropsychol 1989, 12: 699-712.

89. Minden, S.L., Moes, E.J., Orav, J., Kaplan, E. \& Reich, P. Memory impairment in multiple sclerosis. $J$ Clin Exp Neuropsychol 1990, 12: 566-586.

90. Carbotte, R.M., Denburg, S.D., Long, A.A., Singer, J. \& Denburg, J.A. The contribution of disease activity to cognitive deficit in systemic lupus erythematosus (SLE) (Abstract). J Clin Exp Neuropsychol 1987, 9: 64-65.

91. Liang, M.H., Rogers, M., Larson, M. et al. The psychosocia impact of systemic lupus erythematosus and rheumatoid arthritis. Arthritis Rheum 1984, 27: 13-19.

92. Kremer, J.M., Rynes, R.I., Bartholomew, L.E. et al. Nonorganic non-psychotic psychopathology (NONPP) in patients with systemic lupus erythematosus. Semin Arthritis Rheum 1981, 11: 182-189.

93. O'Neill, M.L., Giang, D., Como, P.G. \& Schiffer, R.B. Anxiety and depression as neuropsychiatric symptoms of systemic lupus erythematosus (Abstract). Ann Neurol 1989, 26: 255 .

94. Denburg, S.D., Carbotte, R.M. \& Denburg, J.A. Cognitive impairment in systemic lupus erythematosus: a neuropsychological study of individual and group deficits. $J$ Clin Exp Neuropsychol 1987, 9: 323-339.

95. Gibson, T. \& Myers, A.R. Nervous system involvement in systemic lupus erythematosus. Ann Rheum Dis 1976, 35: 398-406.

96. McCune, W.J., MacGuire, A., Aisen, A. \& Gebarski, S. Identification of brain lesions in neuropsychiatric systemic lupus erythematosus by magnetic resonance scanning. Arthritis Rheum 1988, 31: 159-166.
97. Sibbitt, W.L., Sibbitt, R.R., Ġriffey, R.H., Eckel, C. \& Bankhurst, A.D. Magnetic resonance imaging in the evaluation of acute neuropsychiatric disease in systemic lupus erythematosus. Ann Rheum Dis 1989, 48: 1014-1022.

98. Bell, C.L., Partington, C., Robbins, M., Graziano, F., Turski, P. \& Kornguth, S. Magnetic resonance imaging of central nervous system lesions in patients with lupus erythematosus: correlation with clinical remission and antineurofilament and anticardiolipin antibody titers. Arthritis Rheum 1991, 34: 432-441.

99. Hiraiwa, M., Nonaka, C., Abe, T. \& Iio, M. Positron emission tomography in systemic lupus erythematosus: relation of cerebral vasculitis to PET findings. $\mathrm{Am} \mathrm{J}$ Neuroradiol 1983, 4: 541-543.

100. Volkow, N.D., Warner, N., McIntyre, R. \& Valentine, A. Cerebral involvement in systemic lupus erythematosus. $\mathrm{Am}$ J Physiol Imaging 1988, 3: 91-98.

101. Stoppe, G., Wildhagen, K., Seidel, J.W. et al. Positron emission tomography in neuropsychiatric lupus erythematosus. Neurology 1990, 40: 304-308.

102. Pinching, A.J., Travers, R.L., Hughes, G.R.V., Jones, T. \& Moss, S. Oxygen-15 brain scanning for detection of cerebral involvement in systemic lupus erythematosus. Lancet 1978, 1: $898-900$.

103. Awada, H.H., Mamo, H.L., Luft, A.G., Ponsin, J.C. \& Kahn, M.F. Cerebral blood flow in systemic lupus with and without central nervous system involvement. $J$ Neurol Neurosurg Psychiatry 1987, 50: 1597-1601.

104. Kushner, M.J., Chawluk, M.D., Fazekas, F. et al. Cerebral blood flow in systemic lupus erythematosus with or without cerebral complications. Neurology 1987, 37: 1596-1598.

105. Carbotte, R.M., Denburg, S.D., Denburg, J.A., Nahmias, C. \& Garnett, E.S. Fluctuating cognitive abnormalities and cerebral glucose metabolism in neuropsychiatric systemic lupus erythematosus. J Neurol Neurosurg Psychiat 1992, 55: 1054-1059.

106. Wong, K.L., Woo, E.K.W., Yu, Y.L. \& Wong, R.W.S. Neurological manifestations of systemic lupus erythe 6 matosus: a prospective study. $Q J$ Med 1991, 294: 857-870.

107. Rogers, M.P. Psychiatric aspects. In: Schur, P.H. (ed) The Clinical Management of SLE. Orlando, Florida, Grune \& Stratton, 1983, pp. 189-212.

108. Brody, S. Psychiatric observations in patients treated with cortisone and ACTH. Psychosom Med 1952, 14: 91-94.

109. Lidz, T., Carter, J.O., Lewis, B.L. \& Surrat, C. Effects of ACTH and cortisone on mood and mentation. Psychosom Med 1952, 14: 363-367.

110. Ward, M. \& Studenski, S. The time course of acute psychiatric episodes in SLE. J Rheumatol 1991, 18: 535-539. 